\title{
THE EFFECT OF BULB PLANTING TIME AND TYPE OF MULCH ON THE YIELD OF Allium aflatunense B. Fedtsch.
}

\section{Halina Laskowska, Elżbieta Pogroszewska, Wojciech Durlak, Danuta Kozak}

\author{
University of Life Sciences in Lublin, Institute of Ornamental Plants and Architecture of Landscape \\ Leszczyńskiego 58, 20-068 Lublin, Poland \\ e-mail: halina.laskowska@up.lublin.pl
}

Received: 07.08.2012

\begin{abstract}
The aim of the study was to determine the effect of bulb planting time and the type of mulch on the morphological traits of plants and on bulb yield of Allium aflatunense B. Fedtsch. 'Purple Sensation'. Bulbs of $12 \mathrm{~cm}$ diameter were used as the study material. The bulbs were planted in plots on three dates: September $15^{\text {th }}$, October $1^{\text {st }}$, and October $15^{\text {th }}$. The plantation was mulched after frost with two types of mulch: composted pine bark and wheat straw. Phenological phases of the plants were observed during the growing season. At the full flowering stage, several observations and measurements were taken: length of leaves, length of inflorescence peduncle, peduncle diameter, inflorescence diameter, and number of flowers per inflorescence. After harvest, total numerical and weight yield of bulbs were evaluated as well as number and weight of the largest bulbs (21-22 cm diameter). The study showed that in order to obtain Allium aflatunense of high ornamental value, which is determined by the number of flowers per inflorescence and the inflorescence peduncle diameter, bulbs need to be planted in the middle of September. Bulb planting in October leads to production of inflorescences of greater diameter. The optimum method of Allium aflatunense cultivation which ensures production of good total yield of bulbs, expressed in its weight, is bulb planting on September $15^{\text {th }}$ and soil mulching with composted pine bark or straw. Mulching a plantation of Allium aflatunense planted on September $15^{\text {th }}$ with bark has a positive effect on the number and weight of bulbs of 21-22 cm diameter.
\end{abstract}

Key words: Allium aflatunense, inflorescences, flowers, bulbs, cultivation method, mulching, pine bark, wheat straw

\section{INTRODUCTION}

Ornamental Allium is a large group of perennial plants of varying ornamental value (K r z y m i ńs k a,
2003). It is a plant that is appropriate not only for planting in flower-beds but also for cut flowers cultivation. Some of them are used for forcing (De Hertogh and $\mathrm{Zi} \mathrm{m} \mathrm{mer,} \mathrm{1993).} \mathrm{In} \mathrm{the} \mathrm{cultivation} \mathrm{of} \mathrm{bulbous}$ plants, the proper planting time of bulbs is crucial to obtain good quality of flowers and high yield (K i z i 1 et al., 2008; Mosleh Ud-Deen, 2008; Akpi$\mathrm{n}$ ar and $\mathrm{Bulut}, 2011)$.

Particular species of ornamental Allium differ in resistance to low temperatures. Those that are less resistant to unfavorable weather conditions can undergo mulching. Organic mulch which is placed in the autumn and then left for the entire cultivation period has been successfully used in the cultivation of ornamental plants for several years already. Thanks to the fact that mulch is left until the end of the growing season, the application of herbicides can be significantly limited. R a s m u s s e n and He n rik se n (1990) showed that plantation mulching can have a significant effect on tulip bulb yield. Mulch also protects plants from low temperatures. December is an especially critical month in the cultivation of tulips and other bulbous plants ( $\mathrm{Szlachetka}$ and Drozd, 1990 a, b; Szlachetka et al. 1991). Mulch used as protection from frost (straw, pine needles, leaves, bark, agrotextile) helps maintain a balanced temperature of soil around the plant's root system and protects it from the effects of frequent soil frosting and defrosting.

The aim of the present study was to determine the effect of bulb planting time and the type of mulch on the morphological traits of plants and on bulb yield of Allium aflatunense 'Purple Sensation'. 


\section{MATERIALS AND METHODS}

The study was conducted in the years 20052008 , every year in the period between September $15^{\text {th }}$ and the beginning of the third decade of June, that is, until bulb harvest.

Bulbs of Allium aflatunense B. Fedtsch 'Purple Sensation' of $12 \mathrm{~cm}$ diameter were used as the study material. The bulbs were planted in plots on three dates: September $15^{\text {th }}$ October $1^{\text {st }}$, and October $15^{\text {th }}$. The plantation was mulched after frost with two types of mulch: composted pine bark and wheat straw. Control plots did not have any covering. 30 bulbs were planted in each $1 \mathrm{~m}^{2}$ plot. Prior to planting, the bulbs were soaked for 20 minutes in 1\% solution of Kaptan and $0.7 \%$ solution of Topsin. In the autumn, Azofoska was applied as fertilizer in the amount of $60 \mathrm{~g} \times \mathrm{m}^{-2}$, whereas in the spring - Azofoska as top dressing $\left(30 \mathrm{~g} \times \mathrm{m}^{-2}\right)$ and ammonium nitrate $\left(20 \mathrm{~g} \times \mathrm{m}^{-2}\right)$. The phenological phases of the plants were observed during the growing season: emergence, beginning of flowering $(25 \%$ of blooming plants in the plots), full flowering (75\% of blooming plants in the plots), and end of flowering. The growing period was also determined. At the full flowering stage, several observations and measurements were taken: length of leaves, length of inflorescence peduncle, peduncle diameter, inflorescence diameter, and number of flowers per inflorescence. After harvest bulbs were dried, cleaned and calibrated. Total numerical and weight yield of bulbs were evaluated as well as number and weight of the largest bulbs (21-22 cm diameter).

The experiment was set up in a randomized block design in three replications. One plot was one replication. The results were analyzed statistically by means of two-way analysis of variance, evaluating the significance of differences by means of Tukey's confidence intervals at the level of significance of $=0.05 \%$.

\section{RESULTS}

Depending on the year of the study, the start of flowering of Allium aflatunense was in the period between May $7^{\text {th }}$ and May $21^{\text {st }}$. The earliest flowering was noted in case of bulbs planted on the latest date, that is, October $15^{\text {th }}$. The type of mulch did not affect the start of flowering of Allium aflatunense. Full flowering was observed in the period between May $17^{\text {th }}$ and May $28^{\text {th }}$. The average duration of flowering was between 15 and 20 days, counting from the beginning of flowering until its end. Plants from bulbs planted on October $1^{\text {st }}$, on average, flowered the longest.

Length of the growing period depended on the planting time. The longest growing period, which was on average 88 days, characterized bulbs planted on
September $15^{\text {th }}$, while the shortest one, which lasted on average 85 days, was characteristic for plants from bulbs planted on October $15^{\text {th }}$.

The effect of bulb planting time and mulch on the morphological traits of plants was observed.

The longest leaves were produced by plants that grew from bulbs planted on October $1^{\text {st }}$ and $15^{\text {th }}$ (Table 1). Application of mulch in the cultivation of Allium aflatunense led to production of longer plant leaves. The longest ones were produced by plants that grew from bulbs planted on the earliest date - September $15^{\text {th }}$ inn the plots mulched with straw $(79.8 \mathrm{~cm})$, the shortest ones in the control plots $(76 \mathrm{~cm})$. The largest diameter of inflorescence was obtained in the case of plants that grew from bulbs planted at the earliest date September $15^{\text {th }}(5.7 \mathrm{~mm})$, compared to plants that grew from bulbs planted four weeks later $(5.1 \mathrm{~mm})$. The effect of correlation between bulb planting time and type of mulch applied on the diameter of Allium aflatunense inflorescence was not observed. It was proved that plants with larger inflorescences $(10.8 \mathrm{~cm})$ (Table 2) grew from bulbs planted on October $1^{\text {st }}$ and $15^{\text {th }}$.

Bulb planting time and the correlation between planting time and type of mulch applied has a significant effect on the number of flowers per inflorescence. The most flowers per inflorescence were produced by plants obtained from bulbs planted at the earliest date September $15^{\text {th }}$ (323.2 pcs.), and similarly on October $1^{\text {st }}$ (321.4 pcs.) (Table 2). The correlation of soil mulching and bulb planting time did not have a positive effect on the number of flowers per inflorescence.

The analysis of data concerning total numerical yield of bulbs shows that there was no positive effect of the correlation between planting time of Allium aflatunense B. Fedtsch and type of mulch (Table 3). In the total bulb yield obtained, expressed in pcs $\times \mathrm{m}^{-2}$, the only trend that was observed was an increase in the total number of bulbs along with later planting time. The total weight of daughter bulbs differed depending on bulb planting time. Mulching with bark or straw had a positive effect on the total weight of bulbs (Table 3). The total weight of adventitious bulbs was the highest in the case of the earliest planting time in the plots mulched with bark and straw (24694 g; 2408.7 g). The lowest total weight of bulbs was recorded in the control plots with the same planting time.

The analysis of numerical and weight yield of the largest bulbs, i.e. with a diameter of $21-22 \mathrm{~cm}$, showed that early planting of bulbs and soil mulching led to production of higher yield of daughter bulbs with the greatest diameter (Table 4). The highest number and weight of bulbs -4.1 pcs and $427 \mathrm{~g}$, respectively, were obtained in the plots mulched with bark with the earliest planting time. 
Table 1

The effect of bulb planting time and type of mulch on morphological traits Allium aflatunense. Means for 3 years

\begin{tabular}{|c|c|c|c|c|c|c|c|}
\hline \multirow{2}{*}{$\begin{array}{l}\text { Planting } \\
\text { time }\end{array}$} & \multirow{2}{*}{$\begin{array}{l}\text { Type of } \\
\text { mulch }\end{array}$} & \multicolumn{6}{|c|}{ Morphological traits } \\
\hline & & $\begin{array}{l}\text { Length of } \\
\text { leaves }(\mathrm{cm})\end{array}$ & $\begin{array}{c}\text { Mean for } \\
\text { planting time }\end{array}$ & $\begin{array}{c}\text { Length of } \\
\text { peduncle }(\mathrm{cm})\end{array}$ & $\begin{array}{c}\text { Mean for } \\
\text { planting time }\end{array}$ & $\begin{array}{c}\text { Diameter of } \\
\text { peduncle }(\mathrm{mm})\end{array}$ & $\begin{array}{c}\text { Mean for } \\
\text { planting time }\end{array}$ \\
\hline \multirow{3}{*}{ 15. IX } & Bark & 60.9 & \multirow{3}{*}{$59.7 \mathrm{~A}$} & $78.5 \mathrm{ab}$ & & 5.7 & \multirow{3}{*}{$5.7 \mathrm{~B}$} \\
\hline & Straw & 60.5 & & $78.4 \mathrm{ab}$ & 78.1 & 5.6 & \\
\hline & Control & 57.7 & & $77.3 \mathrm{ab}$ & & 5.7 & \\
\hline \multirow{3}{*}{ 1. $X$} & Bark & 60.2 & \multirow{3}{*}{$60.5 \mathrm{~B}$} & $78.3 \mathrm{ab}$ & & 5.1 & \multirow{3}{*}{$5.3 \mathrm{AB}$} \\
\hline & Straw & 61.8 & & $78.7 \mathrm{ab}$ & 77.8 & 5.5 & \\
\hline & Control & 59.4 & & $76.6 \mathrm{a}$ & & 5.2 & \\
\hline \multirow{3}{*}{ 15. $\mathrm{X}$} & Bark & 62.1 & \multirow{3}{*}{$60.9 \mathrm{~B}$} & 77. $a b$ & & 5.1 & \multirow{3}{*}{$5.1 \mathrm{~A}$} \\
\hline & Straw & 62.1 & & $79.8 \mathrm{~b}$ & 77.7 & 5.1 & \\
\hline & Control & 58.5 & & $76.0 \mathrm{a}$ & & 5.2 & \\
\hline \multirow{3}{*}{$\begin{array}{l}\text { Mean for } \\
\text { mulch }\end{array}$} & Bark & $61.1 \mathrm{~B} *$ & & 78.0 & & 5.3 & \\
\hline & Straw & $61.5 \mathrm{~B}$ & & 78.9 & & 5.4 & \\
\hline & Control & $58.5 \mathrm{~A}$ & & 77.7 & & 5.4 & \\
\hline
\end{tabular}

*Means followed by the same letter are not significantly different at $=0.05$.

Table 2

The effect of bulb planting time and type of mulch on morphological traits of Allium aflatunense. Means for 3 years

\begin{tabular}{|c|c|c|c|c|c|}
\hline \multirow[b]{2}{*}{ Planting time } & \multirow[b]{2}{*}{ Type of mulch } & \multicolumn{4}{|c|}{ Morphological traits } \\
\hline & & $\begin{array}{c}\text { Diameter of } \\
\text { inflorescence }(\mathrm{cm})\end{array}$ & $\begin{array}{c}\text { Mean for } \\
\text { planting time }\end{array}$ & $\begin{array}{c}\text { Number of flowers } \\
\text { per inflorescence }\end{array}$ & $\begin{array}{c}\text { Mean for } \\
\text { planting time }\end{array}$ \\
\hline \multirow{3}{*}{ 15. IX } & Bark & 10.2 & \multirow{3}{*}{$10.4 \mathrm{~A}^{*}$} & $312.8 \mathrm{abc}$ & \multirow{3}{*}{$323.2 \mathrm{~B}$} \\
\hline & Straw & 10.4 & & $328.1 \mathrm{bc}$ & \\
\hline & Control & 10.5 & & $328.7 \mathrm{bc}$ & \\
\hline \multirow{3}{*}{ 1. $\mathrm{X}$} & Bark & 10.8 & \multirow{3}{*}{$10.8 \mathrm{~B}$} & $328.7 \mathrm{bc}$ & \multirow{3}{*}{$321.4 \mathrm{~B}$} \\
\hline & Straw & 10.7 & & $295.4 \mathrm{a}$ & \\
\hline & Control & 11.0 & & $336.1 \mathrm{c}$ & \\
\hline \multirow{3}{*}{ 15. $\mathrm{X}$} & Bark & 10.7 & \multirow{3}{*}{$10.8 \mathrm{~B}$} & $301.8 \mathrm{ab}$ & \\
\hline & Straw & 10.6 & & $299.9 \mathrm{ab}$ & $299.1 \mathrm{~A}$ \\
\hline & Control & 11.1 & & $293.9 \mathrm{a}$ & \\
\hline \multirow{3}{*}{ Mean for mulch } & Bark & 10.6 & & 316.3 & \\
\hline & Straw & 10.6 & & 307.3 & \\
\hline & Control & 10.9 & & 320.1 & \\
\hline
\end{tabular}

*Means followed by the same letter are not significantly different at $=0.05$.

Table 3

The effect of bulb planting time and type of mulch on total numerical (pcs. $\left.\times \mathrm{m}^{-2}\right)$ and weight $\left(\mathrm{g} . \times \mathrm{m}^{-2}\right)$ yield of Allium aflatunense daughter bulbs. Means for 3 years

\begin{tabular}{|c|c|c|c|c|c|}
\hline Planting time & Type of mulch & $\begin{array}{l}\text { Total yield of bulbs } \\
\quad\left(\mathrm{pcs} \times \mathrm{m}^{-2}\right)\end{array}$ & $\begin{array}{c}\text { Mean for } \\
\text { planting time }\end{array}$ & $\begin{array}{l}\text { Total yield of bulbs } \\
\text { in } \mathrm{g} \times \mathrm{m}^{-2}\end{array}$ & $\begin{array}{c}\text { Mean for } \\
\text { planting time }\end{array}$ \\
\hline \multirow{3}{*}{ 15. IX } & Bark & 88.2 & \multirow{3}{*}{86.1} & $2469.4 \mathrm{~g}^{*}$ & \multirow{3}{*}{$2312.8 \mathrm{C}$} \\
\hline & Straw & 85.8 & & $2408.7 \mathrm{f}$ & \\
\hline & Control & 84.4 & & $2060.4 \mathrm{a}$ & \\
\hline \multirow{3}{*}{ 1. $X$} & Bark & 92.3 & \multirow{3}{*}{88.2} & $2217.5 \mathrm{c}$ & \multirow{3}{*}{$2300.6 \mathrm{~B}$} \\
\hline & Straw & 85.9 & & $2388.2 \mathrm{e}$ & \\
\hline & Control & 86.4 & & $2296.2 \mathrm{~d}$ & \\
\hline \multirow{3}{*}{ 15. X } & Bark & 87.1 & \multirow{3}{*}{90.6} & $2134.1 \mathrm{~b}$ & \multirow{3}{*}{$2216.6 \mathrm{~A}$} \\
\hline & Straw & 92.3 & & $2284.4 \mathrm{~d}$ & \\
\hline & Control & 92.4 & & $2231.2 \mathrm{c}$ & \\
\hline \multirow{3}{*}{ Mean for mulch } & Bark & 89.2 & & $2273.8 \mathrm{~B}$ & \\
\hline & Straw & 88.0 & & $2360.4 \mathrm{C}$ & \\
\hline & Control & 87.8 & & $2195.6 \mathrm{~A}$ & \\
\hline
\end{tabular}

*Means followed by the same letter are not significantly different at $=0.05$. 
Table 4

The effect of bulb planting time and type of mulch

on the number and weight of Allium aflatunense daughter bulbs of 21-22 cm diameter. Means for 3 years

\begin{tabular}{|c|c|c|c|c|c|}
\hline Planting time & $\begin{array}{l}\text { Type of } \\
\text { mulch }\end{array}$ & $\begin{array}{l}\text { Number of bulbs } \\
\left(\mathrm{pcs} \times \mathrm{m}^{-2}\right)\end{array}$ & $\begin{array}{c}\text { Mean } \\
\text { for planting time }\end{array}$ & $\begin{array}{l}\text { Weight of bulb } \\
\left(\mathrm{g} \times \mathrm{m}^{-2}\right)\end{array}$ & $\begin{array}{c}\text { Mean } \\
\text { for planting time }\end{array}$ \\
\hline \multirow{3}{*}{ 15. IX } & Bark & $4.1 \mathrm{f}^{*}$ & \multirow{3}{*}{$3.2 \mathrm{~B}$} & $427.0 \mathrm{f}$ & \multirow{3}{*}{$330.9 \mathrm{~B}$} \\
\hline & Straw & $2.2 \mathrm{bc}$ & & $272.4 \mathrm{~cd}$ & \\
\hline & Control & $1.7 \mathrm{a}$ & & $293.4 \mathrm{~d}$ & \\
\hline \multirow{3}{*}{ 1. $\mathrm{X}$} & Bark & $2.7 \mathrm{~cd}$ & \multirow{3}{*}{$2.8 \mathrm{~B}$} & $248.4 \mathrm{abc}$ & \multirow{3}{*}{$304.2 \mathrm{~B}$} \\
\hline & Straw & $3.5 \mathrm{e}$ & & $386.7 \mathrm{e}$ & \\
\hline & Control & $1.9 \mathrm{ab}$ & & $277.4 \mathrm{~cd}$ & \\
\hline \multirow{3}{*}{ 15. X } & Bark & $2.9 \mathrm{~d}$ & \multirow{3}{*}{$1.9 \mathrm{~A}$} & $178.4 \mathrm{a}$ & \\
\hline & Straw & $2.8 \mathrm{~d}$ & & $212.1 \mathrm{ab}$ & $198.9 \mathrm{~A}$ \\
\hline & Control & $2.0 \mathrm{ab}$ & & $206.2 \mathrm{a}$ & \\
\hline \multirow{3}{*}{ Mean for mulch } & Bark & 2.7 & & $284.6 \mathrm{~B}$ & \\
\hline & Straw & 2.7 & & 290.4 B & \\
\hline & Control & 2.6 & & $258.9 \mathrm{~A}$ & \\
\hline
\end{tabular}

*Means followed by the same letter are not significantly different at $=0.05$.

\section{DISCUSSION}

The increasing popularity of this little known, yet incredibly ornamental species of Allium creates a great demand for its bulbs. Bringing to perfection cultivation technology and reproduction of this group of plants is needed to meet the demands of the market.

Planting bulbs at the proper timing is extremely important. The optimum planting time guarantees higher bulb yield and plants of better quality. In the research on patchiness, Kizil et al. (2008) planted bulbs on four dates: September $1^{\text {st }}$ and $15^{\text {th }}$ as well as October $1^{\text {st }}$ and $15^{\text {th }}$. The research showed that the best planting time leading to production of the highest numerical yield of Fritillaria imperialis L. bulbs was the first decade of September. However, that same research showed a trend towards an increase in numerical yield of Allium aflatunense bulbs with later bulb planting time (October), which is not in agreement with the results of the research by Ki zil et al. (2008). The quoted authors claimed that the earlier planting time also affected morphological traits of plants. Bulbs planted at the beginning of September produced the highest plants with the thickest shoots and the greatest number of flowers per inflorescence. This finding has been confirmed by the results of this study where in the case of the earliest planting time, i.e. September $15^{\text {th }}$, a tendency was observed for production of the longest inflorescence peduncles and the largest peduncle diameter in Allium aflatunense. Similarly, the number of flowers per inflorescence was the highest in the case of plants that grew from bulbs planted at the earliest date.

In the present study, the highest weight yield of daughter bulbs was obtained at the earliest planting date. It confirms the results of the research by $\mathrm{Het}$ m a n et al. (2007) where in the cultivation of Allium moly L. the highest weight yield of daughter bulbs was obtained with the earliest planting date (September $29^{\text {th }}$ and October $9^{\text {th }}$ ).

The quality of plants and the size of yield can be improved through application of mulch to the plantation. Mulch improves soil moisture and protects the plant root system from frost. In the present experiment, the application of mulch, depending on bulb planting time, had a positive effect on the length of inflorescence peduncle and also on bulb yield. This confirms the results of studies by other authors. B huiy a et al. (2003) who observed the effect of planting time and mulch on yield of edible garlic proved that earlier planting along with mulching with, e.g., straw increases bulb yield by over $27 \%$. It also leads to increased height of plants and size of bulbs. R e k ow s k a and S ku pień (2007) obtained similar results through application of agrotextile. Yield of bulbs was greater by over $24 \%$ in comparison with plants that were not covered. A positive effect of application of agrotextile on tuber yield was observed in the cultivation of early potato ( $\mathrm{H} \mathrm{a} \mathrm{m} \mathrm{o} \mathrm{u} \mathrm{z}$ et al. 2005). The present research confirms the results obtained by others. Application of pine mulch or wheat straw mulch has positive effect on bulb weight of total yield.

\section{CONCLUSIONS}

1. In order to obtain Allium aflatunense of high ornamental value, with a specific number of flowers per inflorescence and diameter of inflorescence peduncle, bulbs need to be planted in the middle of September. Bulb planting in October leads to production of inflorescence of greater diameter.

2. Optimum method of Allium aflatunense cultivation which ensures production of good total yield of 
bulbs, expressed in its weight, is bulb planting on September $15^{\text {th }}$ and soil mulching with composted pine bark or straw.

3. Mulching a plantation of Allium aflatunense planted on September $15^{\text {th }}$ with bark has a positive effect on the number and weight of bulbs of $21-22 \mathrm{~cm}$ diameter.

\section{Acknowledgments}

The study was financed by the Ministry of Science and Informatization, project no. 2 PO6R 01027.

\section{REFERENCES}

Akpinar E., Bulut Y. 2011. A study on the growth and development of some Gladiolus (Gladiolus L.) varieties planted in different time under the ecological conditions of Erzurum. Afr. J. Agr. Res. 6(13): 3143-3148.

Bhuiya M.A.K., Rahim M.A., Chowdhury M.N.A. 2003. Effect of planting time, mulch and irrigation on the growth and yield of garlic. Asian J. Plant Sci. 2 (8): 639-643.

De Hertogh A.A., Zimmer K. 1993. Allium - ornamental species. In De Hertogh A. A., Le Nard M. The Physiology of Flower Bulbs. Elsevier. Amsterdam, London, New York, Tokyo: 187-200.

Hamouz K., Dvořák P., Čepl J., Pivec J. 2005. The effect of polypropylene fleece covering on the yield of early potatoes. Hort. Sci. (Prague) 32(2): 56-59.

Hetman J., Laskowska H., Durlak W. 2007. The influence of selected factors on the yield of Allium moly L. bulbs. Acta Sci. Pol. Hortorum Cultus, 6(2): 23-27.

Kizil S., Arslan N., Ölmez-Bayhan S., Khawa r K.M. 2008. Effect of different planting dates on improving yield of Fritillaria imperialis L. and Fritillaria persica $\mathrm{L}$. bulbs damaged by small narcissus fly (Eumerus strigatus Fallen). Afr. J. Biotech. 7 (24): 4454-4458.

Krzymińska A. 2003. Fenologia i morfologia wybranych gatunków ozdobnych czosnku (Allium L.). / Phenology and morphology of chosen ornamental species of Allium L. Zesz. Probl. Post. Nauk Rol. 491: 161-168. (in Polish)

Mosleh Ud-Deen MD. 2008. Effect of mother bulb size and planting time on growth, bulb and seed yield of onion. Bangladesh J. Agril. Res. 33 (3): 531-537.

Rasmussen E., Henriksen K. 1990. Tildig daekning af tulipaner. Tidsskrift for Planteavl. 94, 4: 419-422.

Rekowska E., Skupień K. 2007. Influence of flat covers and sowing density on yield and chemical composition of garlic cultivated for bundle-harvest. Veg. Crops Res. Bull. 66: 17-24. http://dx.doi.org/10.2478/ v10032-007-0003-y

Szlachetka W., Drozd J., Drozd W. 1990a. Wpływ warunków meteorologicznych na plon cebul tulipanów w produkcji towarowej. / Effect of meteorological conditions on tulip bulb yield in commercial production. Prace ISiK Skierniewice Seria B, t. 15: 19-25. (in Polish)

Szlachetka W., Drozd J., Drozd W. 1990b. Wpływ warunków meteorologicznych na plon bulw krokusów w produkcji towarowej. / Effect of meteorological conditions on crocus corm yield in commercial production. Prace ISiK Skierniewice Seria B, t. 15: 35-40. (in Polish)

Szlachetka W., Romanowska F., Drozd J., Drozd W. 1991. Grudzień krytycznym miesiącem w uprawie narcyzów, krokusów i tulipanów. / December as a critical month in the cultivation of daffodils, crocuses and tulips. Ogrodnictwo 5-6: 38-39. (in Polish)

\section{Wpływ terminu sadzenia cebul i rodzaju ściółki na plonowanie czosnku aflatuneńskiego (Allium aflatunense B. Fedtsch).}

\section{Streszczenie}

Badano wpływ terminu sadzenia cebul oraz rodzaju ściółki na cechy morfologiczne roślin i plon cebul czosnku aflatuneńskiego 'Purple Sensation'. W doświadczeniu wykorzystano cebule o obwodzie $+12 \mathrm{~cm}$. Cebule były sadzone na poletkach w trzech terminach: 15 września, 1 października i 15 października. Po przymrozkach plantację przykryto dwoma rodzajami ściółek: przekompostowaną korą sosnową i słomą pszenną. W czasie wegetacji obserwowano fazy fenologiczne. Podczas pełni kwitnienia wykonano następujące pomiary i obserwacje: długość liści, długość szypuły kwiatostanowej i jej średnica, średnica kwiatostanu oraz liczba kwiatów w kwiatostanie. Po zbiorze oceniono ogólny plon liczbowy i wagowy oraz liczbę i masę cebul największych (21-22 cm obwodu). Wykazano, że w celu uzyskania czosnku aflatuneńskiego o wysokich walorach dekoracyjnych, określonych liczbą kwiatów w kwiatostanie i średnicą szypuły kwiatostanowej, cebule należy sadzić w połowie września. Sadzenie cebul w październiku umożliwia uzyskanie kwiatostanów o większej średnicy. Optymalnym sposobem uprawy czosnku aflatuneńskiego zapewniającym otrzymanie dobrego plonu ogólnego cebul, wyrażonego jego masą, jest sadzenie cebul 15 IX i ściółkowanie gleby przekompostowaną korą sosnową lub słomą. Ściółkowanie korą plantacji czosnku aflatuneńskiego posadzonego 15 IX korzystnie wpływa na liczbę i masę cebul o obwodzie $21-22 \mathrm{~cm}$. 
